\title{
SELECTION AND IDENTIFICATION OF XYLOSE-FERMENTING YEAST STRAINS FOR ETHANOL PRODUCTION
}

\author{
JULIANA ALVES ARAÚJO1 \\ THIAGO LUCAS ABREU-LIMA² \\ SOLANGE CRISTINA CARREIRO'
}

\begin{abstract}
Ethanol production from lignocellulosic biomass is interesting to the economy due to the pressure to reduce the consumption of fossil fuels and the use of lands for non-edible crops. Xylose is one of the main sugars obtained by hydrolysis of hemicellulose fraction of biomass; however, industrial yeasts cannot ferment it. This work aimed to select, characterize and identify xylosefermenting yeasts from a collection of Brazilian microorganisms with potential use in ethanol production. Xylose assimilation was tested by replica plating, and fermentation was tested with Durham tubes. Xylose-fermenting strains had their fermentative capacity quantified and compared to a reference strain (Scheffersomyces stipitis UFMG-IMH 43.2) and were identified by molecular techniques. Three strains isolated from plant exudates were able to ferment xylose and showed fermentative parameters similar to the reference strain. Two strains were additionally identified as Candida parapsilosis and one was identified as Meyerozyma guilliermondii. The findings show the potential biotechnological use of these microorganisms.
\end{abstract}

KEYWORDS: SCREENING; SECOND GENERATION ETHANO; CANDIDA; MEYEROZYMA; SCHEFFERSOMYCES; NON-SACCHAROMYCES YEAST

1 Laboratório de Microbiologia Aplicada - LAMA - Universidade Federal do Tocantins. CEP 77001-090, Palmas, TO, Brazil.

2 Laboratório de Cinética e Modelagem de Processos - LACIMP - Universidade Federal do Tocantins. CEP 77001-090, Palmas, TO, Brazil.

*Corresponding author

E-mail: abreulimatl@mail.uft.edu.br

Address: Universidade Federal do Tocantins - UFT, Avenida NS 15, ALCNO 14, 109 NORTE s/n. Bloco II, sala 07 Laboratório de Cinética e Modelagem de Processos. Palmas-TO. CEP 77001-090.

Phone: +55 6332294585 


\section{INTRODUCTION}

The industrial technology for ethanol production uses carbohydrates of certain crops such as corn, wheat, sorghum, potatoes, sugar cane, sugar beet, and cassava. The main raw materials for obtaining first generation fuel ethanol are cornstarch in the United States and sucrose from sugar cane in Brazil (MUSSATTO et al., 2010). However, land use for cultivation of such crops competes with food crops and environmental preservation areas. This became the main driving force for the development and implementation of advanced technologies in the production of lignocellulosic (second generation) ethanol from agricultural wastes such as straw, bagasse, wood or grass (LUO; VAN DER VOET; HUPPES, 2009).

Lignocellulosic materials are of great interest as raw materials for production of second generation ethanol due to its wide availability, high polysaccharides content, and, mainly, because they would not affect the land use for food crops. However, while the technologies for ethanol production from sucrose or starch are well established, feasible technologies for ethanol production from lignocellulosic biomass are still under development around the world (MUSSATTO et al., 2010; SOCCOL et al., 2010).

Lignocellulosic material has approximately $20-50 \%$ cellulose, $20-40 \%$ hemicellulose, and $10-20 \%$ lignin in its constitution and from its hydrolysis results a hydrolysate containing pentose and hexose sugars (INGRAM et al., 1999; VAN MARIS et al., 2006). Xylose is a major sugar obtained by hydrolysis of hemicellulose and its bioconversion is an important step in the utilization of lignocellulose to produce ethanol (STAMBUK et al., 2008). Although Saccharomyces cerevisiae is widely used in industrial fermentations, it is not able to ferment xylose. Nonetheless, this is not a general feature observed in other yeasts (VAN MARIS et al., 2006).

Thus, efficient conversion of biomass to ethanol involves the use of microbial strains capable of fermenting not only glucose, but also the main sugars present in lignocellulosic hydrolysates, such as xylose, with high yield and ethanol productivity (VAN MARIS et al., 2006; HAHN-HÄGERDAL et al., 2007). The fermentation of pentose sugars, particularly xylose and arabinose, represents a unique challenge and for achieving efficient fermentation new organisms have been pursued in recent decades (NGUYEN et al., 2006; CADETE et al., 2009, 2013; HOU, 2012; MORAIS et al., 2013).

The present study selected xylose-fermenting yeasts from collections of microbe from the Federal University of Tocantins (UFT). The selected xylose-fermenting yeasts had their fermentative parameters measured and compared to a reference strain to asses their potential for biotechnological processes and had their species identified by molecular techniques.

\section{MATERIALS AND METHODS}

\subsection{MICROORGANISMS}

A total of 160 yeast strains isolated from frozen fruit pulp, belonging to the culture collection of the Laboratory of Applied Microbiology - UFT (group A), were investigated. Another 119 strains isolated from exudates from plants of Cerrado (a Brazilian biome), belonging to the culture collection of the Laboratory of Environmental Microbiology and Biotechnology - UFT (group B), were also used. One yeast strain was used as positive control 
for the assimilation and fermentation of xylose: Scheffersomyces stipitis UFMG-IMH 43.2 (CADETE et al., 2009), isolated from the Brazilian Atlantic Forest, courtesy of the research group of the Laboratory of Yeast Ecology and Biotechnology from the Federal University of Minas Gerais (UFMG). Tests for xylose assimilation and fermentation of glucose were performed with yeasts from groups $A$, since all yeasts from group $B$ were known to assimilate xylose and ferment glucose from previous tests performed in the Laboratory of Environmental Microbiology and Biotechnology (data not shown).

The strains were reactivated by streaking them in Sabouraud agar (glucose $40 \mathrm{~g}^{-\mathrm{L}^{-1}}$, peptone $10 \mathrm{~g} \cdot \mathrm{L}^{-1}$, agar $20 \mathrm{~g} \cdot \mathrm{L}^{-1}$, and chloramphenicol $100 \mathrm{mg} \cdot \mathrm{L}^{-1}$ ), followed by incubation at 30 ${ }^{\circ} \mathrm{C}$ for 48 hours.

\subsection{XYLOSE ASSIMILATION TEST}

The strains of group $A$, as well as the reference strain, were inoculated using the replica plating technique (LEDERBERG; LEDERBERG, 1952) using solid defined medium (yeast nitrogen base $6.7 \mathrm{~g} . \mathrm{L}^{-1}$, agar $18 \mathrm{~g} \cdot \mathrm{L}^{-1}$, carbon source $5 \mathrm{~g} \cdot \mathrm{L}^{-1}$ ). The carbon sources used were glucose (positive control) or xylose (assay medium). The negative control was performed with the same medium without the addition of any carbon source. The plates were incubated at $30{ }^{\circ} \mathrm{C}$ for 20 days to check for growth of colonies.

\subsection{SELECTION OF GLUCOSE AND XYLOSE FERMENTING STRAINS}

The fermentation test was carried out with fermentation medium (yeast extract $4.5 \mathrm{g.L} \mathrm{L}^{-}$ ${ }^{1}$, peptone $7.5 \mathrm{~g} \cdot \mathrm{L}^{-1}$, carbon source $20 \mathrm{~g} \cdot \mathrm{L}^{-1}$ ) in test tubes containing inverted Durham tubes (TOIVOLA et al., 1984). The carbon sources used were glucose or xylose. The negative control was performed with the same medium without the addition of a carbon source. The tubes were incubated at $30^{\circ} \mathrm{C}$ for 8 days and observed every 2 days to check for gas formation. All xyloseassimilating strains selected in the previous test, as well as the strains of group B, were tested. The reference strain was used as positive control.

\subsection{FERMENTATION TEST}

The assay was performed as described by Rao et al. (RAO; BHADRA; SHIVAJI, 2008), nevertheless modifications were maiden. In this test, the xylose fermenting yeast $S$. stipitis IMH - UFMG - 43.2 was used for comparison.

The inocula were produced by cultivating each xylose fermenting yeast in a $250 \mathrm{~mL}$ Erlenmeyer flask with $100 \mathrm{~mL}$ medium (Yeast Nitrogen Base $6.7 \mathrm{~g} \cdot \mathrm{L}^{-1}$, xylose $40 \mathrm{~g} \cdot \mathrm{L}^{-1}$ ) in an orbital shaker at $150 \mathrm{rpm}$ and $30^{\circ} \mathrm{C}$ for $48 \mathrm{~h}$.

The fermentation trials were conducted in $500 \mathrm{~mL}$ Erlenmeyer flasks containing 300 $\mathrm{mL}$ of culture medium (yeast extract $5 \mathrm{~g} . \mathrm{L}^{-1}$, peptone $20 \mathrm{~g} \cdot \mathrm{L}^{-1}$, xylose $40 \mathrm{~g} . \mathrm{L}^{-1}, \mathrm{KH}_{2} \mathrm{PO}_{4} 0.5 \mathrm{~g} . \mathrm{L}^{-1}$, $\left.\left(\mathrm{NH}_{4}\right)_{2} \mathrm{SO}_{4} 0.5 \mathrm{~g} . \mathrm{L}^{-1}, \mathrm{MgSO}_{4} .7 \mathrm{H}_{2} \mathrm{O} 0.5 \mathrm{~g} \cdot \mathrm{L}^{-1}\right)$. The flasks were inoculated with $30 \mathrm{~mL}$ inoculum corresponding to one unit of optical density (OD) at $600 \mathrm{~nm}$. They were incubated in an orbital shaker at $30^{\circ} \mathrm{C}$ and $150 \mathrm{rpm}$ for $120 \mathrm{~h}$. Samples were taken and analyzed at each $24 \mathrm{~h}$ interval. 


\subsection{SUBSTRATE AND PRODUCT ANALYSIS}

The ethanol content was determined by the spectrophotometric method with dichromate oxidation (WILLIAMS; REESE, 1950). The content of reducing sugars was determined by the spectrophotometric method of reaction with DNS (3,5 dinitrosalicylic acid) (MILLER, 1959).

\subsection{STATISTICAL ANALYSIS AND CALCULATION OF FERMENTATION PARAMETERS}

For statistical analysis, data were subjected to analysis of variance (ANOVA) and means were compared by Tukey test $(p<0.05)$ using the Software Microsoft $\AA$ Excel® for Mac 2011.

\subsection{MOLECULAR CHARACTERIZATION OF SELECTED STRAINS}

The D1/D2 region of the 26S ribossomal RNA gene was amplified and sequenced using NL1 and NL4 primers. The sequences were used for identification using the BLAST search (http://www.ncbi.nlm.nih.gov/BLAST/) and compared to the GenBank database (RURIANI; SUNARTI; MERYANDINI, 2012).

To clarify the LAG 647 strain identification, a carbon source assimilation test was conducted. One loopful of a fresh culture was inoculated in test tubes containing growth medium (yeast extract $4.5 \mathrm{~g} \cdot \mathrm{L}^{-1}$, peptone $7.5 \mathrm{~g} \cdot \mathrm{L}^{-1}$, carbon source $20 \mathrm{~g} \cdot \mathrm{L}^{-1}$ ) and the tubes were incubated at $30^{\circ} \mathrm{C}$ for 8 days and observed every 2 days in order to check the growing. Moreover the carbon sources used were glucose (positive control), glycerol or sucrose. Culture medium without a carbon source was used as negative control.

\section{RESULTS}

Among all tested strains, 86 from group A were able to assimilate xylose. From the xylose assimilating strains, 56 from group A could ferment glucose and none of them could ferment xylose. All strains from group $B$ could assimilate xylose and ferment glucose (data not shown) and three of them (LAG 630, LAG 644 and LAG 647) fermented xylose, producing gas in Durham's tube test. Thus, from all 205 xylose-assimilating yeasts, only three isolates (1.46\%) from exudates from plants of Cerrado could ferment xylose and were further characterized and identified. 
TABLE 1 - FERMENTATIVE PARAMETERS OF SELECTED STRAINS AND REFERENCE STRAIN

\begin{tabular}{lllll}
\hline Parameter & LAG 630 & LAG 644 & LAG 647 & $\begin{array}{l}\text { S. stipitis IMH } \\
\text { UFMG 43.2 }\end{array}$ \\
\hline $\mathrm{Y}_{\mathrm{P} / \mathrm{S}}\left(\mathrm{g} \cdot \mathrm{g}^{-1}\right)$ & $0.163 \pm 0.001^{\mathrm{b}}$ & $0.165 \pm 0.004^{\mathrm{b}}$ & $0.186 \pm 0.004^{\mathrm{a}}$ & $0.176 \pm 0.007^{\mathrm{a}, \mathrm{b}}$ \\
$\mathrm{Y}_{\mathrm{X} / \mathrm{S}}\left(\mathrm{g} \cdot \mathrm{g}^{-1}\right)$ & $3.1 \mathrm{E}-3 \pm 1.2 \mathrm{E}-4^{\mathrm{a}}$ & $2.4 \mathrm{E}-3 \pm 7.9 \mathrm{E}-5^{\mathrm{b}}$ & $2.9 \mathrm{E}-03 \pm 1.3 \mathrm{E}-04^{\mathrm{a}}$ & $2.4 \mathrm{E}-03 \pm 1.2 \mathrm{E}-04^{\mathrm{b}}$ \\
$\mathrm{QS}_{\mathrm{S}}\left(\mathrm{g} \cdot \mathrm{L}^{-1} \cdot \mathrm{h}^{-1}\right)$ & $0.304 \pm 0.006^{\mathrm{a}}$ & $0.302 \pm 0.009^{\mathrm{a}}$ & $0.263 \pm 0.010^{\mathrm{b}}$ & $0.300 \pm 0.010^{\mathrm{a}}$ \\
$\mathrm{QP}_{\mathrm{P}}\left(\mathrm{g} \cdot \mathrm{L}^{-1} \cdot \mathrm{h}^{-1}\right)$ & $0.050 \pm 5.5 \mathrm{E}-04^{\mathrm{b}}$ & $0.050 \pm 8.0 \mathrm{E}-04^{\mathrm{a}, \mathrm{b}}$ & $0.049 \pm 1.8 \mathrm{E}-03^{\mathrm{b}}$ & $0.053 \pm 5.1 \mathrm{E}-04^{\mathrm{a}}$ \\
$\mathrm{QX}_{\mathrm{X}}\left(\mathrm{g} \cdot \mathrm{L}^{-1} \cdot \mathrm{h}^{-1}\right)$ & $9.3 \mathrm{E}-04 \pm 1.8 \mathrm{E}-05^{\mathrm{a}}$ & $7.2 \mathrm{E}-04 \pm 1.4 \mathrm{E}-05^{\mathrm{b}}$ & $7.6 \mathrm{E}-04 \pm 1.0 \mathrm{E}-05^{\mathrm{b}}$ & $7.3 \mathrm{E}-04 \pm 1.6 \mathrm{E}-05^{\mathrm{b}}$ \\
\hline
\end{tabular}

${ }^{*}$ Reference strain. Mean values \pm standard deviations from three repetitions. Means in the same row followed by the same superscript letter are not significantly different by the Tukey test ( $5 \%$ significance). Ethanol yield on $x y l o s e\left(Y_{P / S}\right)$, biomass yield on xylose $\left(Y_{\mathrm{X} / \mathrm{S}}\right)$, xylose consumption rate $\left(Q_{S}\right)$, ethanol productivity $\left(Q_{\mathrm{P}}\right)$, biomass productivity $\left(Q_{\mathrm{x}}\right)$.

Some statistically significant $(p \leq 0.05)$ differences in fermentative parameters values were found between the strains. The reference strain showed the highest $Q_{P}$ value and LAG 630 showed the highest $Q_{X}$ value. The strain LAG 647 showed the highest $Y_{P / S}$ value and lowest $Q_{S}$ value. Both LAG 630 and LAG 647 showed the highest $Y_{X / S}$ values (Table 1). The four strains showed a similar fermentative kinetics profile (Fig. 1 a-d). 
FIGURA 1 - TIME COURSE OF XYLOSE FERMENTATION OF LAG 630 (a), LAG 644 (b), LAG 647 (c), AND S. STIPITIS UFMG-IMH 43.2 (d) STRAINS (FILLED CIRCLES XYLOSE, FILLED TRIANGLES ETHANOL, CROSSES BIOMASS). VALUES ARE MEANS OF THREE REPLICATIONS \pm STANDARD DEVIATION

(a)

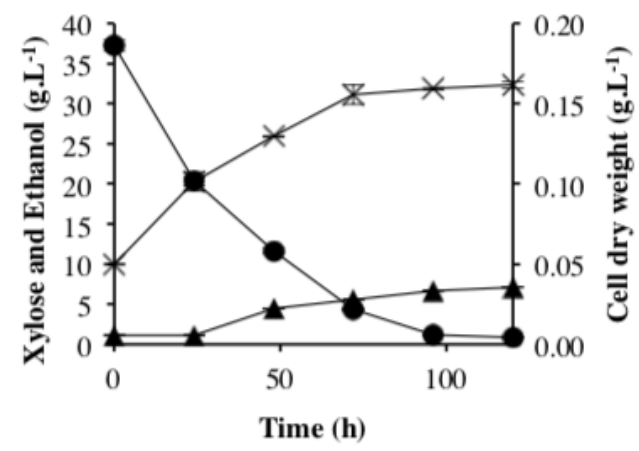

(c)

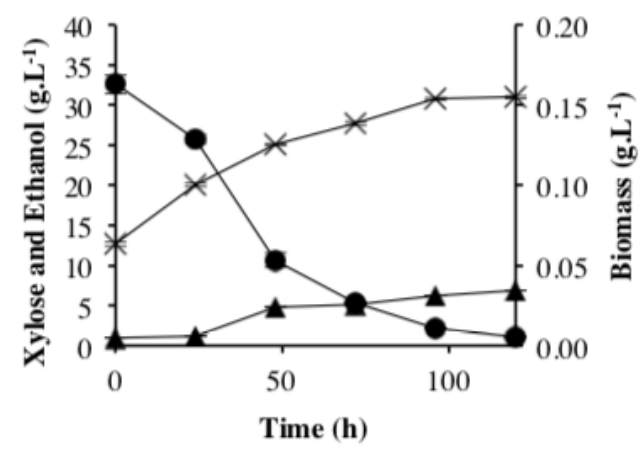

(b)

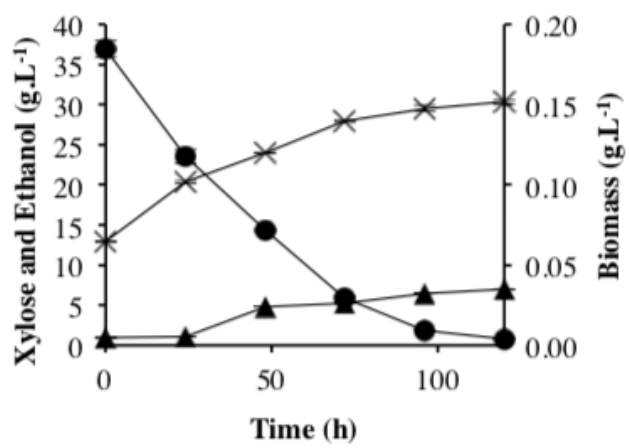

(d)

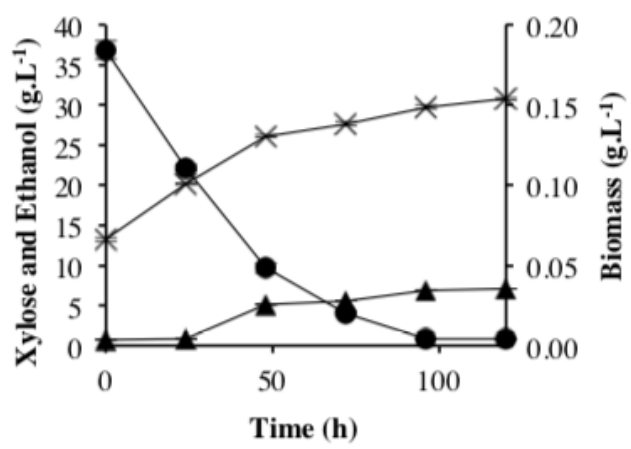

The yeast strains were identified as Candida parapsilosis (LAG 630 and LAG 644) and Meyerozyma guilliermondii (LAG 647). The sequence obtained from LAG 647 strain also showed 100\% identity with Candida carpophila and Brettanomyces naardenensis, but its identification was confirmed by assimilation tests with glycerol and sucrose and observation of its cell morphology in microscope.

\section{DISCUSSION}

Previous screening works also showed a low relative occurrence of xylose-fermenting yeast. Toivola et al. (1984), after screening of 193 type strains of xylose-assimilating and glucose-fermenting yeast species, found only 5 (2.59\%) species (B. naardenensis, Scheffersomyces shehatae, Pachysolen tannophilus, Scheffersomyces segobiensis and S. stipitis) that showed positive results in Durham tube test, but $25(12.95 \%)$ species were able to convert xylose to ethanol when checked by HPLC analysis. Only the species with positive results in Durham tube test reached an ethanol titer higher than 1 g. $\mathrm{L}^{-1}$ (TOIVOLA et al., 1984). 
Four (7.14\%) xylose-fermenting yeast were reported after screening 56 xylose-assimilating yeast isolates. These xylose-fermenting yeasts were further identified as Candida sp., Candida tenuis and S. stipitis (DU-PREEZ; BOSCH; PRIOR, 1985). Insect frass and tree exudates were examined for the presence of xylose-fermenting yeast and 36 (8.74\%) from 412 isolates could ferment xylose (NIGAM et al., 1985). A total of 374 isolates from rotten fruit and bark samples were screened for xylose fermentation to ethanol and $27(7.22 \%)$ isolates showed positive results. The genus of these xylose-fermenting strains were further identified by molecular techniques as Pichia, Candida, Kluyveromyces, Issatchenkia, Zygosaccharomyces, Clavispora, Debaryomyces, Metschnikowia, Rhodotorula, and Cryptococcus (RAO; BHADRA; SHIVAJI, 2008). A group of 28 xylose-assimilating yeast strains were isolated from buffalo feces, in which 27 of them could produce ethanol with xylose as the sole carbon source (LORLIAM et al., 2013). From 92 yeast isolates obtained form the guts of a wood-feeding thermite (Reticulitermes chinensis), only 12 (13.04\%) were able to ferment xylose (ALI et al., 2017). So, although the capacity to ferment xylose is not widespread in yeast species (VAN MARIS et al., 2006), they are usually found in hemicellulose-rich substrate, as reported in the literature.

As Durham tube testing can lead to false negative results for strains that produce a low ethanol titer (TOIVOLA et al., 1984) and the ability to ferment xylose is uncommon, the small number of xylose-fermenting yeast found in this work (1.46\%) was not surprising. Even though Durham tube testing can lead to a false negative result in fermentation screenings (CADETE et al., 2012), it still is a useful technique to screen for yeast strains with a high fermentation capacity.

The $Y_{P / S}$ values for xylose-fermenting yeast cultivated in xylose containing media are diverse, with reported values from 0.07 to $0.45 \mathrm{~g} \mathrm{~g}^{-1}$ in screening works involving several species (FU; PEIRIS, 2008; RAO; BHADRA; SHIVAJI, 2008; CADETE et al., 2012). The $Y_{P / S}$ values for $S$. stipitis also varies, with some reported values of 0.25 (FURLAN; BOUILLOUD; DE CASTRO, 1994), 0.27 (ZHANG; GENG, 2012), 0.22 and 0.28 (CADETE et al., 2012), 0.32 (SILVA; MUSSATTO, 2011), 0.35 (FURLAN; BOUILLOUD; DE CASTRO, 1994), and $0.43 \mathrm{~g} . \mathrm{g}^{-1}$ (DU-PREEZ; BOSCH; PRIOR, 1986). Even product yields of $0.5 \mathrm{~g} \cdot \mathrm{g}^{-1}$, almost as high as the theoretical maximum of $0.511 \mathrm{~g} . \mathrm{g}^{-1}$ for alcoholic fermentation, were observed for $P$. tannophilus (FU; PEIRIS, 2008) and Spathaspora arborariae (CADETE et al., 2009). S. stipitis UFMG-IMH 43.2 showed an $Y_{P / S}$ value of $0.19 \mathrm{~g} \cdot \mathrm{g}^{-1}$ and $Q_{P}$ of $0.13 \mathrm{~g} \cdot \mathrm{L}^{-1} \cdot \mathrm{h}^{-1}$ when cultivated in medium containing sugarcane bagasse hemicellulose hydrolysate (FERREIRA et al., 2011). Two $C$. parapsilosis strains isolated from buffalo feces presented low $Y_{P / S}$ values, 0.01 and $0.09 \mathrm{~g} . \mathrm{g}^{-1}$, when they were cultivated in medium containing $60{\mathrm{~g} . \mathrm{L}^{-1}}^{-1}$ xylose (LORLIAM et al., 2013).

The mid to low $Y_{P / S}$ values obtained in the present work, in comparison with the literature, ranging from 0.163 to $0.186 \mathrm{~g} \cdot \mathrm{g}^{-1}$, probably occurred due to cultivation conditions. The main factor influencing the fermentative performance of xylose-fermenting yeasts is aeration (DU-PREEZ, 1994), since it influences the division of substrate flux in cell growth or product formation. A high aeration rate can inhibit fermentation and anaerobiosis can severely inhibit growth and fermentation (WATSON et al., 1984; SKOOG; HAHN-HÄGERDAL, 1988; FURLAN; BOUILLOUD; DE CASTRO, 1994; PESSOA; MANCILHA; SATO, 1996; SILVA; MUSSATTO, 2011). The balance between cell growth and ethanol production can be found in a microaerophilic environment (FURLAN; BOUILLOUD; DE CASTRO, 1994; UNREAN; NGUYEN, 2013), which is hard to achieve in flask cultures.

The agitation and $\mathrm{V}_{\text {flask }} / \mathrm{V}_{\text {medium }}$ ratio can be used as an estimative of aeration in fermentations using Erlenmeyer flasks. In $S$. stipitis cultivation, the highest $Y_{P / S}$ and $Q_{P}$ values 
were observed with $200 \mathrm{rpm}$ agitation and 2.5 ratio (SILVA; MUSSATTO; ROBERTO, 2010). In the present work, the agitation was $150 \mathrm{rpm}$ and the $\mathrm{V}_{\text {flask }} / \mathrm{V}_{\text {medium }}$ ratio was 1.66 (500 mL flask and $300 \mathrm{~mL}$ medium). That could lead to a lower oxygen transfer rate. The lower oxygen availability can inhibit cell growth and be the reason of small values of $\mathrm{Y}_{\mathrm{X} / \mathrm{S}}(2.4 \mathrm{E}-03$ to $3.1 \mathrm{E}-03$ $\left.\mathrm{g} \cdot \mathrm{g}^{-1}\right)$ and $\mathrm{Q}_{\mathrm{X}}\left(7.2 \mathrm{E}-04\right.$ to $\left.9.3 \mathrm{E}-04 \mathrm{~g} \cdot \mathrm{L}^{-1} \cdot \mathrm{h}^{-1}\right)$. Since ethanol is a primary metabolite, those values negatively influenced $Y_{P / S}, Q_{S}$ and $Q_{P}$. Two ways to circumvent those limitations would be increase the aeration rate or calculate the specific fermentation parameters for comparisons, taking the $X$ values into consideration.

Both species identified in the this work have already shown biotechnological potential. M. guilliermondii was cultivated in hydrolysates from corn cob residues (FAN et al., 2013), sugar cane bagasse (SILVA; MUSSATTO, 2011), and soybean hull (SCHIRMER-MICHEL et al., 2008) for ethanol and/or xylitol production. The improvement of this species was also tried by triggering its respirofermentative metabolism by disruption of CAT8 gene, what increased its ethanol titer by more than 20-fold (QI; ZHONG; XIA, 2014). C. parapsilosis is reported to have potential to produce xylitol (KIM; KIM; OH, 1997; FURLAN; CASTRO, 2001), ethanol (AWAN; TSUKAMOTO; TASIC, 2013) or single cell protein (SILVA et al., 2011).

None of the strains evaluated in this work showed outstanding fermentative parameters, but all of them, LAG 647 in special, showed a fermentative profile similar to the $S$. stipitis IMH - UFMG - 43.2, a reference strain.

\section{CONCLUSION}

The tree exudate isolated is an adequate source of xylose-fermenting yeast. The three xylose-fermenting strains characterized showed fermentation profile similar to the reference strain, an indication that they have potential for utilization in biotechnological processes for second generation ethanol production or in strain improvement by mutagenesis, evolutionary engineering or recombinant DNA techniques, as genetic or metabolic engineering.

\section{ACKNOWLEDGEMENTS}

This work was supported by grants and fellowships from the Brazilian agency Coordenação de Aperfeiçoamento de Pessoal de Nível Superior (CAPES). The authors are very thankful to Dr. Paula Benevides de Morais (Laboratory of Environmental Microbiology and Biotechnology - UFT) and Dr. Carlos Augusto Rosa and Dr. Raquel Miranda Cadete (Laboratory of Yeast Ecology and Biotechnology - UFMG) for providing strains and helping with the molecular identification of selected strains.

Conflict of Interest: The authors declare that they have no conflict of interest.

\section{REFERENCES}

1 ALI, S. S.; WU, J.; XIE, R.; ZHOU, F.; SUN, J.; HUANG, M. Screening and characterizing of xylanolytic and xylose-fermenting yeasts isolated from the wood-feeding termite, Reticulitermes chinensis. PLoS ONE, v. 12, n. 7, p. 1-21, 2017. 
2 AWAN, A. T.; TSUKAMOTO, J.; TASIC, L. Orange waste as a biomass for 2G-ethanol production using low cost enzymes and co-culture fermentation. RSC Advances, v. 3, p. 25071-25078, 2013. Disponível em: <http://pubs.rsc.org/en/content/articlehtml/2013/ra/c3ra43722a>. Acesso em: 6 out. 2014.

3 CADETE, R. M.; MELO, M. A.; DUSSÁN, K. J.; RODRIGUES, R. C. L. B.; SILVA, S. S.; ZILLI, J. E.; VITAL, M. J. S.; GOMES, F. C. O.; LACHANCE, M. A.; ROSA, C. A. Diversity and physiological characterization of $\mathrm{D}$-xylose-fermenting yeasts isolated from the Brazilian Amazonian Forest. PLoS ONE, v. 7, n. 8, 2012.

4 CADETE, R. M.; MELO, M. A.; ZILLI, J. E.; VITAL, M. J. S.; MOURO, A.; PROMPT, A. H.; GOMES, F. C. O.; STAMBUK, B. U.; LACHANCE, M.-A.; ROSA, C. A. Spathaspora brasiliensis sp. nov., Spathaspora suhii sp. nov., Spathaspora roraimanensis sp. nov. and Spathaspora xylofermentans sp. nov., four novel (D)-xylose-fermenting yeast species from Brazilian Amazonian forest. Antonie van Leeuwenhoek, v. 103, n. 2, p. 421-31, fev. 2013. Disponível em: <http://www.ncbi.nlm.nih.gov/pubmed/23053696>. Acesso em: 23 set. 2013.

5 CADETE, R. M.; SANTOS, R. O.; MELO, M. A.; MOURO, A.; GONÇALVES, D. L.; STAMBUK, B. U.; GOMES, F. C. O.; LACHANCE, M.-A.; ROSA, C. A. Spathaspora arborariae sp. nov., a dxylose-fermenting yeast species isolated from rotting wood in Brazil. FEMS yeast research, v. 9, $\mathrm{n}$. 8, p. 1338-42, dez. 2009. Disponível em: <http://www.ncbi.nlm.nih.gov/pubmed/19840117>. Acesso em: 25 set. 2013.

6 DU-PREEZ, J. C. Process parameters and environmental factors affecting D-xylose fermentation by yeasts. Enzyme and microbial technology, v. 16, p. 944-956, 1994. Disponível em: <http://www.sciencedirect.com/science/article/pii/0141022994900035>. Acesso em: 4 out. 2014.

7 DU-PREEZ, J. C.; BOSCH, M.; PRIOR, B. A. Xylose fermentation by Candida shehatae and Pichia stipitis: effects of $\mathrm{pH}$, temperature and substrate concentration. Enzyme and Microbial Technology, v. 8 , n. 6, p. 360-364, jun. 1986. Disponível em: <http://linkinghub.elsevier.com/retrieve/pii/0141022986901365>.

8 FAN, C.; QI, K.; XIA, X.-X.; ZHONG, J.-J. Efficient ethanol production from corncob residues by repeated fermentation of an adapted yeast. Bioresource technology, v. 136, p. 309-15, maio 2013. Disponível em: <http://www.ncbi.nlm.nih.gov/pubmed/23567696>. Acesso em: 26 set. 2014.

9 FERREIRA, A. D.; MUSSATTO, S. I.; CADETE, R. M.; ROSA, C. A.; SILVA, S. S. Ethanol production by a new pentose-fermenting yeast strain ,Scheffersomyces stipitis UFMG-IMH 43.2 , isolated from the Brazilian forest. Yeast, n. May, p. 547-554, 2011.

10 FU, N.; PEIRIS, P. Co-fermentation of a mixture of glucose and xylose to ethanol by Zymomonas mobilis and Pachysolen tannophilus. World Journal of Microbiology and Biotechnology, v. 24, n. 7, p. 1091-1097, 27 nov. 2008. Disponível em: <http://link.springer.com/10.1007/s11274-0079613-2>. Acesso em: 27 set. 2013.

11 FURLAN, S. A.; BOUILLOUD, P.; DE CASTRO, H. F. Influence of oxygen on ethanol and xylitol production by xylose fermenting yeasts. Process Biochemistry, v. 29, n. 8, p. 657-662, jan. 1994. Disponível em: <http://linkinghub.elsevier.com/retrieve/pii/003295929480043X>.

12 FURLAN, S. A.; CASTRO, H. F. Xylitol production by Candida parapsilosis under fed-batch culture. Brazilian archives of biology and technology, v. 44, n. 2, p. 125-128, 2001. Disponível em: <http://www.scielo.br/scielo.php?pid=S1516-89132001000200003\&script=sci_arttext>. Acesso em: 6 out. 2014.

13 HAHN-HÄGERDAL, B.; KARHUMAA, K.; FONSECA, C.; SPENCER-MARTINS, I.; GORWAGRAUSLUND, M. F. Towards industrial pentose-fermenting yeast strains. Applied microbiology and biotechnology, v. 74, n. 5, p. 937-953, abr. 2007. Disponível em: <http://link.springer.com/article/10.1007/s00253-006-0827-2>. Acesso em: 12 jul. 2014.

$14 \mathrm{HOU}, \mathrm{X}$. Anaerobic xylose fermentation by Spathaspora passalidarum. Applied microbiology and biotechnology, v. 94 , n. 1, p. 205-14, abr. 2012. Disponível em: <http://www.ncbi.nlm.nih.gov/pubmed/22124720>. Acesso em: 23 set. 2013. 
15 INGRAM, L. O.; ALDRICH, H. C.; BORGES, A. C. C.; CAUSEY, T. B.; MARTINEZ, A.; MORALES, F.; SALEH, A.; UNDERWOOD, S. A.; YOMANO, L. P.; YORK, S. W.; ZALDIVAR, J.; ZHOU, S. Enteric Bacterial Catalysts for Fuel Ethanol Production. Biotechnology Progress, v. 15, p. 855866, 1999. Disponível em: <htps://onlinelibrarywiley.ez6.periodicos.capes.gov.br/doi/full/10.1021/bp9901062>.

16 KIM, S. Y.; KIM, J. H.; OH, D. K. Improvement of Xylitol Production by Controlling Oxygen Supply in Candida parapsilosis. Journal of fermentation and bioengineering, v. 83, n. 3, p. 3-6, 1997. Disponível em: <http://www.sciencedirect.com/science/article/pii/S0922338X97809907>. Acesso em: 6 out. 2014

17 LEDERBERG, J.; LEDERBERG, E. M. Replica plating and indirect selection of bacterial mutants. Journal of bacteriology, v. 63, n. 3, p. 399-406, mar. 1952. Disponível em: $<\mathrm{http}: / /$ www.pubmedcentral.nih.gov/articlerender.fcgi?artid=1203627\&tool=pmcentrez\&rendertype $=$ abstract>.

18 LORLIAM, W.; AKARACHARANYA, A.; SUZUKI, M.; OHKUMA, M.; TANASUPAWAT, S. Diversity and fermentation products of xylose-utilizing yeasts isolated from buffalo feces in Thailand. Microbes Environ, v. 28, n. 3, p. 354-360, 2013. Disponível em: <http://jlc.jst.go.jp/DN/JST.JSTAGE/jsme2/ME13023?from=Google>. Acesso em: 6 out. 2014.

19 LUO, L.; VAN DER VOET, E.; HUPPES, G. Life cycle assessment and life cycle costing of bioethanol from sugarcane in Brazil. Renewable and Sustainable Energy Reviews, v. 13, n. 6-7, p. 1613-1619, ago. 2009.2 Disponível em: <http://linkinghub.elsevier.com/retrieve/pii/S1364032108001627>. Acesso em: 14 jul. 2014.

20 MILLER, G. L. Use of dinitrosalicylic acid reagent for determination of reducing sugar. Analytical chemistry, v. $31, \quad$ n. 3 , p. 426-428, 1959. Disponível em: <http://pubs.acs.org/doi/abs/10.1021/ac60147a030>. Acesso em: 6 out. 2014.

21 MORAIS, C. G.; CADETE, R. M.; UetAnABARO, A. P. T.; ROSA, L. H.; LACHANCE, M.-A.; ROSA, C. A. D-xylose-fermenting and xylanase-producing yeast species from rotting wood of two Atlantic Rainforest habitats in Brazil. Fungal genetics and biology : FG \& B, v. 60, p. 19-28, nov. 2013. Disponível em: <http://www.ncbi.nlm.nih.gov/pubmed/23872280>. Acesso em: 27 jan. 2014.

22 MUSSATTO, S. I.; DRAGONE, G.; GUIMARÃES, P. M. R.; SILVA, J. P. A.; CARNEIRO, L. M.; ROBERTO, I. C.; VICENTE, A.; DOMINGUES, L.; TEIXEIRA, J. A. Technological trends, global market, and challenges of bio-ethanol productionBiotechnology AdvancesElsevier Inc., , 2010. . Disponível em: <http://dx.doi.org/10.1016/j.biotechadv.2010.07.001>.

23 NGUYEN, N. H.; SUH, S.-O.; MARSHALL, C. J.; BLACKWELL, M. Morphological and ecological similarities: wood-boring beetles associated with novel xylose-fermenting yeasts, Spathaspora passalidarum gen. sp. nov. and Candida jeffriesii sp. nov. Mycological research, v. 110, n. Pt 10, p. 1232-41, out. 2006. Disponível em: <http://www.ncbi.nlm.nih.gov/pubmed/17011177>. Acesso em: 29 jan. 2014.

24 NIGAM, J. N.; IRELAND, R. S.; MARGARITIS, A.; LACHANCE, M. A. Isolation and screening of yeasts that ferment D-xylose directly to ethanol. Applied and environmental microbiology, v. 50, n. 6, p. 1486-1489, 1985. Disponível em: <http://aem.asm.org/content/50/6/1486.short>. Acesso em: 6 out. 2014 .

25 PESSOA, A.; MANCILHA, I.; SATO, S. Cultivation of Candida tropicalis in sugar cane hemicellulosic hydrolyzate for microbial protein production. Journal of Biotechnology, v. 51, n. 1, p. 83-88, 1996. Disponível em: <http://www.sciencedirect.com/science/article/pii/0168165696015726>. Acesso em: 6 out. 2014.

26 QI, K.; ZHONG, J.-J.; XIA, X.-X. Triggering respirofermentative metabolism in the crabtree-negative yeast Pichia guilliermondii by disrupting the CAT8 gene. Applied and environmental microbiology, v. 80 , n. 13 , p. 3879-87, 1 jul. 2014 . Disponível em: <http://www.ncbi.nlm.nih.gov/pubmed/24747899>. Acesso em: 6 set. 2014.

27 RAO, R. S.; BHADRA, B.; SHIVAJI, S. Isolation and characterization of ethanol-producing yeasts from fruits and tree barks. Letters in applied microbiology, v. 47, n. 1, p. 19-24, jul. 2008. Disponível em: <http://www.ncbi.nlm.nih.gov/pubmed/18498317>. Acesso em: 9 set. 2014. 
28 RURIANI, E.; SUNARTI, T. C.; MERYANDINI, A. Yeast Isolation for Bioethanol Production. HAYATI Journal of Biosciences, v. 19, n. 3, p. 145-149, 1 set. 2012. Disponível em: <http://journal.ipb.ac.id/index.php/hayati/article/view/5632>. Acesso em: 6 set. 2014.

29 SCHIRMER-MICHEL, A. C.; FlÔRES, S. H.; HERTZ, P. F.; MATOS, G. S.; AYUB, M. A. Z. Production of ethanol from soybean hull hydrolysate by osmotolerant Candida guilliermondii NRRL Y-2075. Bioresource technology, v. 99, n. 8, p. 2898-904, maio 2008. Disponível em: <http://www.ncbi.nlm.nih.gov/pubmed/17706417>. Acesso em: 3 out. 2014.

30 SILVA, J. P. A.; MUSSATTO, S. I. Ethanol production from xylose by Pichia stipitis NRRL Y-7124 in a stirred tank bioreactor. Braz J Chem Eng, v. 28, n. 01, p. 151-156, 2011. Disponível em: <http://www.scielo.br/scielo.php?pid=S0104-66322011000100016\&script=sci_arttext>. Acesso em: 6 out. 2014.

31 SILVA, J. P. A.; MUSSATTO, S. I.; ROBERTO, I. C. The influence of initial xylose concentration, agitation, and aeration on ethanol production by Pichia stipitis from rice straw hemicellulosic hydrolysate. Applied biochemistry and biotechnology, v. 162, n. 5, p. 1306-15, nov. 2010. Disponível em: <http://www.ncbi.nlm.nih.gov/pubmed/19946760>. Acesso em: 6 out. 2014.

32 SILVA, C. F.; ARCURI, S. L.; CAMPOS, C. R.; VILELA, D. M.; ALVES, J. G. L. F.; SCHWAN, R. F. Using the residue of spirit production and bio-ethanol for protein production by yeasts. Waste management (New York, N.Y.), v. 31, n. 1, p. 108-14, jan. 2011. Disponível em: <http://www.ncbi.nlm.nih.gov/pubmed/20864326>. Acesso em: 3 out. 2014.

33 SKOOG, K.; HAHN-HÄGERDAL, B. Xylose fermentation. Enzyme and Microbial Technology, v. 10, p. 66-80, 1988.

34 SOCCOL, C. R.; VANDENBERGHE, L. P. de S.; MEDEIROS, A. B. P.; KARP, S. G.; BUCKERIDGE, M.; RAMOS, L. P.; PITARELO, A. P.; FERREIRA-LEITÃO, V.; GOTTSCHALK, L. M. F.; FERRARA, M. A.; BON, E. P. da S.; MORAES, L. M. P. de; ARAÚJO, J. de A.; TORRES, F. A. G. Bioethanol from lignocelluloses: Status and perspectives in Brazil. Bioresource technology, v. 101, n. 13, p. 4820-5, jul. 2010. Disponível em: <http://www.ncbi.nlm.nih.gov/pubmed/20022746>. Acesso em: 30 jan. 2013.

35 StAmBuK, B. U.; EleUtheriO, E. C. A.; MARINA, L.; MARIA, F. A.; BON, E. P. S. Brazilian potential for biomass ethanol : Challenge of using hexose and pentose co- fermenting yeast strains. v. 67, n. November, p. 918-926, 2008.

36 TOIVOLA, A.; YARROW, D.; BOSCH, E. van den; VAN DIJKEN, J. P.; SCHEFFERS, W. A. Alcoholic fermentation of $D$-xylose by yeasts. Applied and environmental microbiology, v. 47, $n$. 6, p. 1221-1223, 1984. Disponível em: <http://aem.asm.org/content/47/6/1221.short>. Acesso em: 6 out. 2014.

37 UNREAN, P.; NGUYEN, N. H. A. Optimized Fed-Batch Fermentation of Scheffersomyces stipitis for Efficient Production of Ethanol from Hexoses and Pentoses. Applied Biochemistry and Biotechnology, v. 169, n. 6, p. 1895-1909, 24 jan. 2013. Disponível em: <http://link.springer.com/10.1007/s12010-013-0100-y>. Acesso em: 25 set. 2013.

38 VAN MARIS, A. J. A.; ABBOTT, D. A.; BELLISSIMI, E.; VAN DEN BRINK, J.; KUYPER, M.; LUTTIK, M. A. H.; WISSELINK, H. W.; SCHEFFERS, W. A.; VAN DIJKEN, J. P.; PRONK, J. T. Alcoholic fermentation of carbon sources in biomass hydrolysates by Saccharomyces cerevisiae: current status. Antonie van Leeuwenhoek, v. 90, n. 4, p. 391-418, nov. 2006. Disponível em: <http://www.ncbi.nlm.nih.gov/pubmed/17033882>. Acesso em: 26 out. 2012.

39 WATSON, N. E.; PRIOR, B. A.; DU-PREEZ, J. C.; LATEGAN, P. M. Oxygen requirements for dxylose fermentation to ethanol and polyols by Pachysolen tannophilus. Enzyme and Microbial Technology, $\quad$ v. 6, p. 447-450, 1984. Disponível em: <http://www.sciencedirect.com/science/article/pii/0141022984900942>. Acesso em: 6 out. 2014.

40 WILLIAMS, M. B.; REESE, H. D. Colorimetric determination of ethyl alcohol. Analytical chemistry, v. 22, n. 12, p. 1556-1561, 1950. Disponível em: <http://pubs.acs.org/doi/abs/10.1021/ac60048a025>. Acesso em: 6 out. 2014. 
41 ZHANG, W.; GENG, A. Improved ethanol production by a xylose-fermenting recombinant yeast strain constructed through a modified genome shuffling method. Biotechnology for biofuels, v. 5 ,
n. 1 ,
$p$.
46 ,
jan.
Disponível
em:

$<$ http://www.pubmedcentral.nih.gov/articlerender.fcgi?artid=3463424\&tool=pmcentrez\&rendertype= abstract>. Acesso em: 5 fev. 2013. 